\title{
STEROIDS FROM THE MARINE FUNGUS GEOTRICHUM SP.
}

\author{
AURELIO SAN-MARTÍN*A, SILVIA OREJARENAA ${ }^{*}$ CLAUDIA GALLARDOB, MARIO SILVA ${ }^{B}$, JOSE BECERRA ${ }^{B}$, \\ RODRIGO REINOSO ${ }^{B}$, MARIA C. CHAMYA ${ }^{A}$ KAREN VERGARA AND JUANA ROVIROSA ${ }^{A}$.
}

\author{
${ }^{a}$ Departamento de Química, Facultad de Ciencias, Universidad de Chile, Casilla 653, Santiago, Chile. \\ ${ }^{b}$ Laboratorio de Química de Productos Naturales, Universidad de Concepción, Concepción, Chile.
}

(Received: 17 December 2007 - Accepted: 6 December 2007)

\begin{abstract}
Ergosterol $\underline{\mathbf{1}}$, peroxyergosterol $\underline{\mathbf{2}}$, ergosta-4,6,8(14), 22-tetraen-3-one $\underline{\mathbf{3}}$ and 24-ethyl-cholesta-4-ene-3-one $\underline{\mathbf{4}}$ were isolated from the cultures of a fungus Geotrichum sp. obtained from a marine sediment. It was established that no other sterols were present in the extract. Their structures were elucidated by spectroscopic methods.
\end{abstract}

Keywords: sterols, ergostane type sterol, ergosterol, peroxyergosterol, marine fungus.

\section{INTRODUCTION}

Marine microorganisms have recently gained attention as important sources of chemically interesting and biologically active secondary metabolites for the development of new pharmaceutical agents. In particular, marine-derived fungi have shown great potential as suggested by the diversity of secondary metabolites, including many that have novel carbon skeletons ${ }^{1}$. Although most metabolites from marine fungi are closely related to constituent of their terrestrial relatives. Based on these findings and literature survey, we believed that marine fungi are rapidly becoming recognized as potentially useful sources of compound with biomedical interest.

As part of our studies on secondary metabolites from marine organisms ${ }^{2}$ from the Chilean coast, we have investigated the chemical constituents obtained from fermentation of a facultative marine fungus strain $2 \mathrm{~S} 21$. This fungus belongs to the genus Geotrichum, Arthrosporae Order, Deuteromycetes Class, Eumycotas group. It was isolated from a marine sediment collected at a depth of ca. $88 \mathrm{~m}$ off in Concepción Bay, VIII Región, Chile. Geotrichum is a yeast-like fungus, found worldwide in soil, water, air, and sewage, as well as in plants, cereals, and dairy products ${ }^{3}$, whose primary mode of reproduction is the formation of arthrospores. This paper describes the isolation and structure elucidation of four steroids: ergosterol $\underline{\mathbf{1}}$, peroxyergosterol $\underline{\mathbf{2}}$, ergosta-4,6,8(14), 22-tetraen-3-one $\underline{\mathbf{3}}$ and 24-ethyl-cholesta-4-ene-3-one $\underline{4}$.

\section{EXPERIMENTAL}

General: Melting points were determined on a Kofler hot-stage apparatus and are uncorrected. IR spectra were recorded on a Nicolet Impact 420 spectrophotometer. ${ }^{1} \mathrm{H}$ and ${ }^{13} \mathrm{C}$ NMR were recorded with a Bruker $\mathrm{AX}-400$ spectrometer, with TMS as int. stand. and $\mathrm{CDCl}_{3}$ as solvent. HPLC was made with Merck Hitachi equipment with refraction index detector. Sephadex LH-20 (25-100 $\mu \mathrm{m})$ and Silica Gel (200-300 and 300-400 mesh) were used for open column chromatography and silica HF-254 for TLC. Spots were detected on TLC by heating after spraying with $10 \% \mathrm{H}_{2} \mathrm{SO}_{4}$ in $\mathrm{MeOH}$.

Fungal material and fermentation.- The strain of Geotrichum sp. was obtained from a cultive of a marine sediment collected using a surface-deployed sediment grab, at a depth of ca. $88 \mathrm{~m}$ off Concepción Bay, VIII Región, Chile. A voucher specimen $\left(\mathrm{N}^{\circ} 05 /\right.$ Geotrichum $)$ is deposited at the laboratory of marine natural products, Facultad de Ciencias, U. de Chile. The colour mycelium is cream and changing to brown at mature, without apparent fructification in the solid medium cultive and with a relatively fast grown. When observing the mycelium by optical microscope, we can see morphologic differences of their hyphae, for instance, we can see the presence of thin hyphae with reproductive structures like chlamidospores and also cenocitic bulky hyphae with the presence of artrospores and chlamidospores. Both hyphae are hyalines in sterile distilled water, and with floxine they are dyed to red. The chlamidospores are extended, of several size but at the moment of the maturity reaches a length of 4 to $5 \mu \mathrm{m}$ by $2-2.5$ wide, with thick walls and the presence of vacuoles or substances of reserve in the poles, and like the hyphae they are hialinic in distilled water. The arthrospores are also hialinic in water. Blastoconidia production is not found.

Culture Conditions.- The initial culture $(50 \mathrm{~mL})$ was grown in Czapek (glucose free) media made with filtered Valparaíso bay seawater-based media adjusted to $\mathrm{pH} 7.3$ with shaking $(150 \mathrm{rpm})$ for 21 days at room temperature (25 $\left.{ }^{\circ} \mathrm{C}\right)$. This initial culture was sprayed over the solid substrate using $250 \mathrm{~g}$ of rice imbibed with a Czapek medium containing of $5 \%$ sucrose, $0.1 \%$ yeast extract, $0.05 \% \mathrm{KH}_{2} \mathrm{PO}_{4}, 0.2 \% \mathrm{NaNO}_{3}, 0.05 \% \mathrm{MgSO}_{4} 7 \mathrm{H}_{2} \mathrm{O}$ and $0.001 \% \mathrm{FeSO}_{4} 7 \mathrm{H}_{2} \mathrm{O}$ adjusted to $\mathrm{pH} 7.0$ contained in 2 sterilized culture bottle (1L), and incubated at $25^{\circ} \mathrm{C}$ under $12 \mathrm{~h} \mathrm{light} / 12 \mathrm{~h}$ dark conditions for 5 weeks. The fermentation mixture was broken up with a spatula and extracted twice with EtOAc $(2 \times 500$ $\mathrm{mL}$ ). The combined EtOAc solution was filtered and evaporated to afford a crude extract $(800 \mathrm{mg})$.

Extraction and Isolation. - The crude extract was fractionated on a Sephadex LH-20 column (Length $75.0 \mathrm{~cm}$, internal diameter $5.0 \mathrm{~cm}$ ) using a 6:2:1 hexane/ $\mathrm{CH}_{2} \mathrm{Cl}_{2} / \mathrm{MeOH}$ solvent system to afford 70 fractions $(125 \mathrm{~mL}$ each). Fractions with similar TLC profile were combined and reduced to 10 fractions (A - J). Each one was rechromatographed on silica gel column (200300 mesh) with a gradient solvent system from petroleum ether/EtOAc to $100 \%$ EtOAc. The fractions were monitored by TLC. Eluates obtained from fractions C-E, after purification by HPLC (Silica gel normal phase column and hexane/ EtOAc 20\%) afforded ergosterol $\underline{\mathbf{1}}(30 \mathrm{mg})$ and ergosterol peroxide $\underline{\mathbf{2}}$ $(80 \mathrm{mg}$ ). These compounds were identified by comparing its physical constants and spectral data with those reported in the literature ${ }^{4}$.

Fractions F-H were further purified by repeated preparative TLC on $\mathrm{Si}$ gel and developed with a mixture of EtOAc/petroleum ether (1:4) to give compounds $\underline{\mathbf{3}}(10 \mathrm{mg})$ and $\underline{4}(7 \mathrm{mg})$.

Compound 3: yellow plates; $\mathrm{mp} 115-116^{\circ} \mathrm{C}$ IR $v^{\mathrm{CHCl}}{ }_{3} \operatorname{max~cm}{ }^{-1}: 2980$, 1675-1640, 1590, 1270, 1233, 975, 880. MS: $m / e(\%): 392^{3}\left(\left[\mathrm{M}^{+}\right], 19.5\right), 377$ ([M+Me], 1.5), 349 (1.5), 268 (42), 253 (6), 240 (3.5), 214 (7.5), 173 (7), 129 (6); ${ }^{1} \mathrm{HNMR}\left(400 \mathrm{MHz}, \mathrm{CDCl}_{3}\right) \delta: 6.67(1 \mathrm{H}, d, J=9.5 \mathrm{~Hz}, \mathrm{H}-7), 6.09(1 \mathrm{H}, d, J$ $=9.5 \mathrm{~Hz}, \mathrm{H}-6), 5.78(1 \mathrm{H}, s, \mathrm{H}-4), 5.26$ and $5.29(1 \mathrm{H}$ each, $d, J=7.7 \mathrm{~Hz}, \mathrm{H}-22$ and $\mathrm{H}-23), 2.50(1 \mathrm{H}, d d d, J=5.2,14.2,14.5 \mathrm{~Hz}, \mathrm{H}-2 \mathrm{a}), 2.45(1 \mathrm{H}, d d d, J=5.2$, $14.2,14.5 \mathrm{~Hz}, \mathrm{H}-2 \mathrm{~b}), 1.08$ (3H, $d, J=6.5 \mathrm{~Hz}, \mathrm{Me}-21), 1.04$ (3H, $s, \mathrm{Me}-18)$, $1.00(3 \mathrm{H}, s, \mathrm{H}-19), 0.97(3 \mathrm{H}, d, J=6.8 \mathrm{~Hz}, \mathrm{Me}-28), 0.89(3 \mathrm{H}, d, J=6.5 \mathrm{~Hz}$, Me-26), 0.87 (3H, $d, J=6.5 \mathrm{~Hz}, \mathrm{Me}-27) .{ }^{13} \mathrm{CNMR} \delta: 34.2(\mathrm{C}-1), 34.1(\mathrm{C}-2)$, 199.5 (C-3), 123.0 (C-4), 164.4 (C-5), 124.5 (C-6), 134.0 (C-7), 124.4 (C-8), 44.4 (C-9), 36.8 (C-10), 25.4 (C-11), 34.2 (C-12), 44.0 (C-13), 156.1 (C-14), 27.7 (C-15), 19.0 (C-16), 55.7 (C-17), 19.0 (C-18), 16.7 (C-19), 39.3 (C-20), 21.2 (C-21), 135.0 (C-22), 132.6 (C-23), 42.9 (C-24), 33.1 (C-25), 19.7 (C-26), 20.0 (C-27), 17.7 (C-28).

Compound 4: yellow oil; IRv ${ }^{\mathrm{CHCl}}{ }_{3} \operatorname{max~} \mathrm{cm}^{-1}: 1650,1380$. MS m/e(\%): $412.0\left[\mathrm{M}^{+}\right]$(76.9), $398.0(11.1), 397\left[\mathrm{M}^{+}-\mathrm{CH}_{3}\right](11.5), 383\left[\mathrm{M}^{+}-\mathrm{C}_{2} \mathrm{H}_{5}\right](2.8)$, 370.0 (28.9), 288.0 (22.9), $289.0(31.8), 275.0(10.5), 271.0\left[\mathrm{M}^{+}-\mathrm{C}_{10} \mathrm{H}_{21}\right](20.5)$, 229.0 (59.1), 230.0 (16.9), 147.0 (23.0), 149.0 (18.6), $148.0(13.7), 137.0$ (11.5), 135.0 (20.3), 133.0 (12.8), 124.0 (100.0), 123.0 (15.8), 121.0 (15.9), 95.0 (20.8), 81.0 (15.8). ${ }^{1} \mathrm{HNMR}\left(400 \mathrm{MHz}, \mathrm{CDCl}_{3}\right) \delta: 5.77(1 \mathrm{H}, s, \mathrm{H}-4), 2.41$ $(2 \mathrm{H}, d d d, J=17,17$, and $5.0 \mathrm{~Hz}, \mathrm{H}-2), 1.30(3 \mathrm{H}, s, \mathrm{Me}-19), 1.22(3 \mathrm{H}, s, \mathrm{Me}-18)$, $0.98(3 \mathrm{H}, d, J=6.5 \mathrm{~Hz}, \mathrm{Me}-21), 0.88(6 \mathrm{H}, d, J=6.5 \mathrm{~Hz}, \mathrm{Me}-26$ and $\mathrm{Me}-27)$, $0.75(3 \mathrm{H}, t, J=6.7 \mathrm{~Hz}, \mathrm{Me}-29) .{ }^{13} \mathrm{CNMR} \delta: 38.6(\mathrm{C}-1), 34.0(\mathrm{C}-2), 199.7(\mathrm{C}-3)$, 123.8 (C-4), 171.7 (C-5), 33.0 (C-6), 32.1 (C-7), 35.7 (C-8), 53.9 (C-9), 35.7 (C-10), 21.1 (C-11), 39.7 (C-12), 42.4 (C-13), 55.9 (C-14), 24.2 (C-15), 29.2 (C-16), 56.1 (C-17), 12.0 (C-18), 17.4 (C-19), 36.1 (C-20), 18.7 (C-21), 33.9 (C-22), 26.1 (C-23), 45.9 (C-24), 29.7 (C-25), 19.8 (C-26), 19.1 (C-27), 23.1 (C-28), 14.0 (C-29).

\section{RESULTS AND DISCUSSION}

Analysis of the ${ }^{1} \mathrm{HNMR}$ and ${ }^{13} \mathrm{CNMR}$ spectra of the compounds $\underline{\mathbf{1}}, \underline{\mathbf{2}}$ and $\underline{\mathbf{3}}$ 
and the comparison with the literature ${ }^{5,6,7}$ data, indicated that these compounds have an ergostane-type side chain with a 22E,24R-configuration. In general, fungi only produces sterols with the $24 \beta$ configuration ( $24 \alpha$-methyl group), indicating aphylogenetic significance of the configuration at C-245. This is consistent with the assignment of the side chain configuration at C-24 for compounds $\mathbf{1}, \underline{\mathbf{2}}$ and $\underline{\mathbf{3}}$, by ${ }^{1} \mathrm{HNMR}$ and ${ }^{13} \mathrm{CNMR}$ spectroscopy. The assignments of the proton signals (H-26 and H-27) and the carbon signals (C-26 and C-27) were made according to literature values. ${ }^{8}$. Compounds $\underline{\mathbf{1}}$ and $\underline{\mathbf{2}}$ were identified as ergosterol and ergosterol peroxide by comparing its physical constants and spectral data with those reported in the literature ${ }^{4}$ (See Figure 1). Ergosterol is frequently found in fungi extracts, because is part of the cytoplasmic membrane of this organism. Similarly, ergosterol peroxide is a common natural product which has been obtained from a variety of lichens ${ }^{9}$, fungi ${ }^{10}$, sponges and marine organisms $\mathrm{s}^{11}$. It was reported that ergosterol peroxide inhibited the growth of cancer cells, showed a potent inhibition on lipid peroxidation and exhibited higher antioxidant activity ${ }^{12}$

Compound $\underline{\mathbf{3}}$ was obtained as yellow crystals with mp. $115^{\circ}-116^{\circ} \mathrm{C}$. It represented a ketosteroidal compound with molecular formula $\mathrm{C}_{28} \mathrm{H}_{40} \mathrm{O}$ which was deduced by the MS $(392 \mathrm{~m} / \mathrm{e})$ and ${ }^{13} \mathrm{CNMR}$ spectra. By the analysis of its ${ }^{1} \mathrm{HNMR}$ and ${ }^{13} \mathrm{CNMR}$ spectra, compound $\underline{\mathbf{3}}$ was identified as ergosta4,6,8(14), 22-tetraen-3-one (See Figure 1). This compound has been obtained from Lampteromyces japonicus ${ }^{13}$ and from a luminous bacterium ${ }^{14}$ and the bioluminescence displayed by this microorganism is related to the presence of this compound. However, it has also been found in no luminous Basidiomycetes mushroom such as Fomes officinalis and Scleroderma polyrhizum ${ }^{15}$, furthermore, it has been isolated from a marine sponge ${ }^{16}$. This is the first time that this compound is isolated from a facultative marine fungus.

Compound $\underline{4}$ was obtained as yellow oil. The IR spectrum showed signals for an unsaturated carbonyl function at $1650,1380 \mathrm{~cm}^{-1}$. The MS spectrum showed a molecular ion at 412 , and together with the ${ }^{13} \mathrm{CNMR}$ data indicated a molecular formula of $\mathrm{C}_{20} \mathrm{H}_{48} \mathrm{O}$. The ${ }^{1} \mathrm{HNMR}$ spectrum showed a series of methyl resonances at $1.30(3 \mathrm{H}, s, \mathrm{Me}-19), 1.22(3 \mathrm{H}, \mathrm{s}, \mathrm{Me}-18), 0.98(3 \mathrm{H}, d$, $J=6.5 \mathrm{~Hz}, \mathrm{Me}-21), 0.88(6 \mathrm{H}, d, J=6.5 \mathrm{~Hz}, \mathrm{Me}-26$ and $\mathrm{Me}-27), 0.75(3 \mathrm{H}, t, J=$ $6.7 \mathrm{~Hz}, \mathrm{Me}-29)$ clearly indicative of a steroidal structure with a keto function at $\mathrm{C}-3$. The ${ }^{1} \mathrm{HNMR}$ indicates that this compound has only one double bond conjugated with the ketone. The ${ }^{13} \mathrm{CNMR}$ indicated the presence of 29 carbons. The skeleton signals indicated that we were in the presence of a cholestane skeleton and that the side chain must have an additional ethyl group at C-24. The nature of the side chain was established by the ${ }^{1}$ HNMR data of $\underline{4}: \delta 0.88$ (Me-26 and Me-27), 0.98 (Me-21) and 0.75 (Me-29). Assignments were made with the aid of extensive decoupling experiments and confirmed by comparison with literature data ${ }^{5}$. So, compound 4 is the known 24-ethyl-cholesta-4-ene-3one $e^{5}$ See Figure 1)<smiles>CC(C)C(C)/C=C/C(C)C1CCC2C3=CC=C4CC(O)CCC4(C)C3CCC21C</smiles>

$\underline{1}$<smiles>CC(C)C(C)/C=C/C(C)C1CCC2=C3C=CC4=CC(=O)CCC4(C)C3CCC21C</smiles>

$\underline{\mathbf{3}}$<smiles>CC(C)C(C)/C=C/C(C)C1CCC2C1(C)CCC1C23C=CC2(CC(O)CCC12C)O3</smiles>

$\underline{2}$<smiles>CCC(CCC(C)C1CCC2C3CCC4=CC(=O)CCC4(C)C3CCC12C)C(C)C</smiles>

$\underline{4}$

\section{REFERENCES}

1. T. S. Bugni, C. M. Ireland, Nat. Prod. Rep. 21, 143, (2004), and references therein.

2. A. R. Díaz-Marrero, J. Darias, K. Painemal, J. Rovirosa, A. San-Martín, J. Chil. Chem. Soc. 51, 775, (2006) and references therein.

3. A. C. Bouakline, N. Lacroix, J. P. Roux, F. Gangneux, F. Derouin, J. Clin. Microbiol. 38, 4272, (2000).

4. M. D. Greca, L. Mangoni, A. P. Molinaro, L. Monaco, C. Previtera, Gazz. Chim. It. 120, 391,(1990).

5. J. L. Wright, A. G. McInnes, S. Shimizu, D. G. Smith, J. A. Walter, D. Idler, W. Khalil, Can. J. Chem. 56, 1898, (1978).

6. V. Piccialli, D. Sica, J. Nat. Prod. 50, 910, (1987).

7. M. Kobayashi, F. Kanda, J. Chem. Soc. Perkin Trans, 1,1177,(1991).

8. W. Zhou, D. Guo, W. D. Nes, T. Letters, 37, 1339, (1996).

9. M. Piovano, M. C. Chamy and J. A. Garbarino, Bol. Soc. Chil. Quim., 46, $023(2001)$

10. A. San-Martin, K. Painemal, Y. Díaz, C. Martinez, J. Rovirosa, J. Argent. Chem. Soc., 93, 247 (2005).

11. C. Jimenez, E. Quinoa, L. Castedo, R. Riguera, J. Nat. Prod., 49, 905(1986)

12. K. Yasukawa, T. Akihisa, H. Kanno, T. Kaminaga, M. Izumida, T. Sakoh, T. Tamura, M Takido, Biol. Pharm. Bull. 19, 573, (1996).

13. M. Endo, M. Kajiwara, K. Nakanishi, J. Chem. Soc. Chem. Commun., 309, (1970).

14. R. L. Airth, G. E. Foerster, J. Cell Comp. Physiol. 56,173, (1960).

15. A. G. González, J. Bermejo, F. J. Toledo, Phytochemistry, 22, 1049, (1983)

16. P. Ciminiello, E. Fattorusso, S. Magno, A. Mangoni, M. Pansini, J. Nat. Prod. 52, 1331, (1983).

\section{ACKNOWLEDGEMENTS}

This work was supported by a research Grant $\mathrm{N}^{\circ} 1040895$ from FONDECYT and "Proyecto Anillo ACT-38".

Figure 1: Steroids isolated from Geotrichum sp. 